\title{
OS PARÂMETROS DE PROTEÇÃO DAS MIGRAÇÕES NO SISTEMA INTERAMERICANO DE DIREITOS HUMANOS
}

\section{STANDARDS OF MIGRATION PROTECTION IN THE INTER- AMERICAN HUMAN RIGHTS SYSTEM}

IVETTE ESIS

Professora e Pesquisadora da Universidad Autónoma de Chile (Chile). Pós-Doutora em Direito (Centro Universitário de Brasília, UniCEUB e Universidade Federal de Uberlândia), com financiamento do Programa PNPD-CAPES; Doutora em Direito Internacional (Universidad de Valencia, Espanha).Mestre em Direito Internacional Privado e Comparado (Universidad Central de Venezuela, Venezuela).

THIAGO PALUMA

Professor da Faculdade de Direito da Universidade Federal de Uberlândia (UFU), no curso de bacharelado em Direito e no Programa de Pós-Graduação em Direito). Doutor em Direito Internacional pela Universidad de Valencia, Espanha. Diretor de Inovação e Transferência de Tecnologia da PROPP/UFU. Membro associado da ASADIP (Asociación Americana de Derecho Internacional Privado).

\section{BIANCA GUIMARÃES SILVA}

Mestranda no Programa de Pós-Graduação em Direito da Universidade de Brasília. Graduada em Direito pela Universidade Federal de Uberlândia. Email: biancaguimaraes18@hotmail.com 


\section{RESUMO}

Objetivos: $O$ presente artigo tem como objetivo principal atestar, sistematizar e analisar os parâmetros de proteção dos direitos humanos dos migrantes no âmbito do Sistema Interamericano de Direitos Humanos.

Metodologia: Adotou-se uma abordagem de caráter histórico, teórico e bibliográfico, a partir de método qualitativo e de pesquisa bibliográfica e documental. Utilizou-se jurisprudências e pareceres consultivos da Corte Interamericana no lapso temporal de 1999 a 2018.

Resultados: Os resultados afirmam a existência de dez parâmetros protetivos e apontam que o estabelecimento de critérios objetivos de aplicação dos parâmetros orienta a sua implementação de maneira adequada. A partir da análise realizada, constatou-se que a Corte fomenta a proteção integral e multidisciplinar do imigrante, visando protegê-lo em todos as fases migratórias, sobretudo em situações pertinentes ao continente americano como a detenção migratória, a irregularidade documental e a vulnerabilidade dos migrantes.

Contribuições: A relevância deste estudo é demonstrada no contexto da multidisciplinaridade das migrações, em que a sua proteção seja integral e contemple todas as fases migratórias: desde a saída de um indivíduo do seu Estado de origem até a chegada no Estado receptor, bem como os possíveis casos de deportação, trânsito ou estadia permanente.

Palavras-chave: Migração Internacional; parâmetros de proteção; Corte Interamericana de Direitos Humanos.

\section{ABSTRACT}

Objective: The main objective of this article is to attest, systematize and analyze the parameters for the protection of the human rights of migrants within the framework of the Inter-American Human Rights System.

Methodology: A historical, theoretical and bibliographic approach was adopted using a qualitative method and bibliographic and documentary research. The jurisprudence and advisory opinions of the Inter-American Court were used in the period from 1999 to 2018.

Results: The results affirm the existence of ten protective parameters and point out that the establishment of objective criteria for the application of the parameters guides its implementation in an appropriate manner. The Court promotes the full and multidisciplinary protection of immigrants, aiming to protect them in all migratory 
phases, especially in situations pertinent to the American continent, such as migratory detention, documentary irregularities and the vulnerability of immigrants.

Contributions: The relevance of this study is demonstrated in the context of the multidisciplinary nature of migration, in which its protection is comprehensive and includes all migratory phases: from the departure of an individual from his country of origin to the arrival in the receiving country, as well as possible cases deportation, transit or permanent stay.

Keywords: International migration; standard of protection; Inter-American Court of Human Rights.

\section{INTRODUÇÃO}

Um dos campos emergentes da agenda global é a temática migratória. A ebulição das discussões sobre direitos humanos ao longo do século $X X$ fez com que a proteção das pessoas deslocadas fosse uma das realidades mais complexas dentro deste debate.

Este estudo, portanto, objetiva atestar a existência, sistematizar e analisar os parâmetros estabelecidos pela jurisprudência interamericana sobre a migração. Após a sistematização, a análise ocorrerá em três etapas: 1) a descrição da situação no continente, por meio de dados estatísticos; 2) o estabelecimento de uma relação entre os eventos, isto é, entre os dados e os parâmetros determinados na jurisprudência interamericana avaliando a sua relevância, necessidade e atualidade; e, 3) os critérios de aplicação de cada parâmetro.

Neste sentido, o presente artigo não tem por objetivo realizar uma análise puramente normativa, mas principalmente jurisprudencial, tendo como base a jurisprudência interamericana. Trata, portanto, dos parâmetros estabelecidos pelo Sistema Interamericano de Direitos Humanos para fomentar a proteção dos direitos humanos dos migrantes.

Esta delimitação metodológica faz-se em razão de um cenário particular das migrações internacionais no continente americano. O tema, em perspectiva regional, 
revela-se complexo devido aos elevados índices de desigualdade social e instabilidade política enfrentados por diversos Estados da América.

A relevância deste estudo é demonstrada em diferentes contextos. A multidisciplinariedade das migrações faz com que a sua proteção seja integral e contemple todas as fases migratórias: desde a saída de um indivíduo do seu Estado de origem até a chegada no Estado receptor, bem como os possíveis casos de deportação, trânsito ou estadia permanente.

Outra preocupação regional recorrente diz respeito aos imigrantes indocumentados. A violação dos direitos humanos dos deslocados irregulares é agravada em razão da sua condição clandestina. Tais violações invocam a responsabilidade estatal frente à proteção de todas as pessoas que se encontrem sob a sua jurisdição, sem discriminar aspectos como nacionalidade, documentação ou status migratório.

O trabalho realizado pelo Sistema Interamericano de Direitos Humanos foi publicado por meio de decisões (jurisprudência), opiniões consultivas e relatórios. Assim, este estudo utilizará esses instrumentos disponibilizados nas plataformas online das instituições para analisar os parâmetros protetivos estabelecidos pela Corte Interamericana de Direitos Humanos (também identificada como Corte, Corte IDH, CoIDH).

Ao longo desta pesquisa, foram identificados oito pressupostos e quatro opiniões consultivas que lidam diretamente com a migração. Tais documentos dedicaram-se a interpretar os direitos assegurados pela Convenção Interamericana de Direitos Humanos e estabelecer critérios de implementação.

Este trabalho será desenvolvido em três partes. A primeira dedica-se à sistematização dos artigos e, consequentemente, dos parâmetros interamericanos de proteção. A segunda e a terceira são destinadas às análises dos parâmetros. Optou-se pela divisão dos artigos em dois blocos: o primeiro trata de parâmetros gerais atinentes à proteção dos direitos humanos aplicáveis também à migração; e o segundo traz princípios específicos aos deslocamentos internacionais.

A pesquisa apontou que a delimitação de princípios interamericanos de proteção dos migrantes é uma urgência na agenda continental. Este estudo 
apresenta o avanço jurisprudencial até abril de 2020 A construção da proteção dos direitos humanos dos migrantes no âmbito regional é cíclica, constante e evolutiva.

\section{SISTEMATIZAÇÃO DOS PARÂMETROS E APORTES INICIAIS PARA A ANÁLISE}

A estrutura do Sistema Interamericano de Direitos Humanos (SIDH) é composta por três elementos fundamentais: a Convenção Americana de Direitos Humanos (CADH), a Comissão Interamericana de Direitos Humanos (CIDH) e a Corte Interamericana de Direitos Humanos (CoIDH). Essa arquitetura regional busca cumprir funções, como promover, controlar e garantir o respeito aos direitos humanos no continente americano (BOBBIO, 2004, p. 62).

Observa-se que a Corte Interamericana possui duas competências distintas: a consultiva e a contenciosa. A jurisprudência da Corte vem aperfeiçoando-se quanto à proteção dos direitos e utiliza-se, além das decisões, dos pareceres consultivos. Ledesma (2004, p. 238) destaca as duas principais funções dessas opiniões: os Estados possuem a oportunidade de conhecer a interpretação da Corte acerca de determinado artigo da Convenção, bem como podem utilizar-se dessa interpretação para assegurar a vigência dos direitos humanos.

O presente estudo dedicou-se à análise dos precedentes e pareceres consultivos que dizem respeito à categoria ${ }^{1}$ de violações aos direitos dos grupos vulneráveis com ênfase na temática migratória. Tal escolha foi motivada pela urgência em assegurar uma migração segura e regular, uma vez que esses movimentos entre jurisdições urgem pela prestação cooperada entre os Estados.

Nesta seção serão apresentadas duas tabelas e um gráfico, que sintetizam a primeira etapa a ser executada pela presente pesquisa. A tabela 1 diz respeito à

\footnotetext{
1 Dentre as temáticas tratadas por este tribunal observam-se questões predominantes, como violações que refletem: o legado do regime autoritário ditatorial, acerca da justiça de transição, os desafios a respeito do fortalecimento de instituições e da consolidação do Estado de Direito, aos direitos de grupos vulneráveis, aos direitos sociais e aos desafios da nova agenda contemporânea (PIOVESAN, 2017, p. 1362-1371).
} 
seleção dos documentos que serão utilizados para a análise interpretativa dos parâmetros interamericanos. Os critérios que diferenciam os documentos escolhidos dos demais existentes são três: órgão emissor, natureza e temática.

Deste modo, dentre os diversos instrumentos emitidos pelo Sistema Interamericano de Direitos Humanos, para fins desta pesquisa, foram utilizados os documentos relacionados à migração, seja de natureza consultiva ou contenciosa, emitidos pela Corte Interamericana de Direitos Humanos. A partir desses filtros foram encontrados 12 documentos no âmbito interamericano que possuíam essas características em comum. A tabela abaixo revela as peculiaridades de cada caso selecionado.

Tabela 1: Sistematização dos documentos de acordo com a data de publicação, natureza e a temática

\begin{tabular}{|c|c|c|c|c|}
\hline & Natureza & $\begin{array}{c}\text { Sentença/Opinião } \\
\text { Consultiva }\end{array}$ & Publicação & Temática \\
\hline 1 & Consultiva & Opinião Consultiva 16 & $\begin{array}{l}1 \text { de outubro de } \\
1999\end{array}$ & $\begin{array}{l}\text { Direito à informação sobre a } \\
\text { assistência Consular }\end{array}$ \\
\hline 2 & Consultiva & $\begin{array}{l}\text { Opinião Consultiva } 18 \\
\text { (Solicitada pelo México) }\end{array}$ & $\begin{array}{l}17 \text { de setembro } \\
\text { de } 2003\end{array}$ & $\begin{array}{l}\text { Condição jurídica e direitos dos } \\
\text { migrantes indocumentados }\end{array}$ \\
\hline 3 & Contenciosa & Tibi vs. Equador & $\begin{array}{l}7 \text { de setembro } \\
\text { de } 2004\end{array}$ & $\begin{array}{l}\text { Privação de liberdade ilegal e } \\
\text { condições de detenção }\end{array}$ \\
\hline 4 & Contenciosa & $\begin{array}{l}\text { Crianças Yean Bosico vs. } \\
\text { República Dominicana }\end{array}$ & $\begin{array}{l}8 \text { de setembro } \\
\text { de } 2005\end{array}$ & Apátrida \\
\hline 5 & Contenciosa & $\begin{array}{l}\text { Acosta Calderón vs. } \\
\text { Equador }\end{array}$ & $\begin{array}{l}24 \text { de junho de } \\
2005\end{array}$ & $\begin{array}{l}\text { Detenção arbitrária e devido } \\
\text { processo legal }\end{array}$ \\
\hline 6 & Contenciosa & Vélez Loor vs. Panamá & $\begin{array}{l}23 \text { de novembro } \\
\text { de } 2010\end{array}$ & $\begin{array}{l}\text { Más condições no centro de } \\
\text { detenção e falta de devido } \\
\text { processo legal }\end{array}$ \\
\hline 7 & Consultiva & Opinião Consultiva 21 & $\begin{array}{l}19 \text { de agosto de } \\
2014\end{array}$ & $\begin{array}{l}\text { Direitos e proteção das } \\
\text { crianças e adolescentes em } \\
\text { contexto de migração }\end{array}$ \\
\hline 8 & Contenciosa & Nadege $\quad$ Dorzema & 24 de outubro & Morte e violação à integridade \\
\hline
\end{tabular}




\begin{tabular}{|l|l|l|l|l|}
\hline & & $\begin{array}{l}\text { outros vs. República } \\
\text { Dominicana }\end{array}$ & de 2012 & $\begin{array}{l}\text { física por autoridades policiais; } \\
\text { Ausência de investigação }\end{array}$ \\
\hline 9 & Contenciosa & $\begin{array}{l}\text { Família Pacheco Tineo } \\
\text { vs. Bolívia }\end{array}$ & $\begin{array}{l}25 \text { de novembro } \\
\text { de } 2013\end{array}$ & $\begin{array}{l}\text { Refúgio e Princípio da Não } \\
\text { Devolução }\end{array}$ \\
\hline 10 & Contenciosa & $\begin{array}{l}\text { Personas Dominicanas e } \\
\text { Haitianas expulsas vs. } \\
\text { República Dominicana }\end{array}$ & 28 de agosto de & $\begin{array}{l}\text { Expulsão coletiva, devido } \\
\text { processo legal, integridade } \\
\text { física e pessoal }\end{array}$ \\
\hline 11 & Contenciosa & Wong Ho Wing vs. Peru & $\begin{array}{l}30 \text { de junho de } \\
2015\end{array}$ & Processo de Extradição \\
\hline 12 & Consultiva & Opinião Consultiva 25 & $\begin{array}{l}30 \text { de maio de } \\
2018\end{array}$ & Instituição do asilo \\
\hline
\end{tabular}

Fonte: Disponível em: <http://www.corteidh.or.cr/cf/Jurisprudencia2/index.cfm?lang=es>. Acesso em 7 de abril de 2020.

Após filtrar os casos consultivos e contenciosos que seriam utilizados para a presente análise, foi necessário extrair de cada texto quais artigos da Convenção Americana de Direitos Humanos foram empregados. Observa-se que na maioria dos casos mais de um artigo foi invocado ao mesmo tempo. Deste modo, o gráfico 2 demonstra a incidência da utilização dos artigos nos 12 casos, bem como avalia a frequência com a qual eles são invocados pela Corte.

Gráfico 1: Sistematização da incidência dos artigos interpretados pela Corte Interamericana de Direitos Humanos

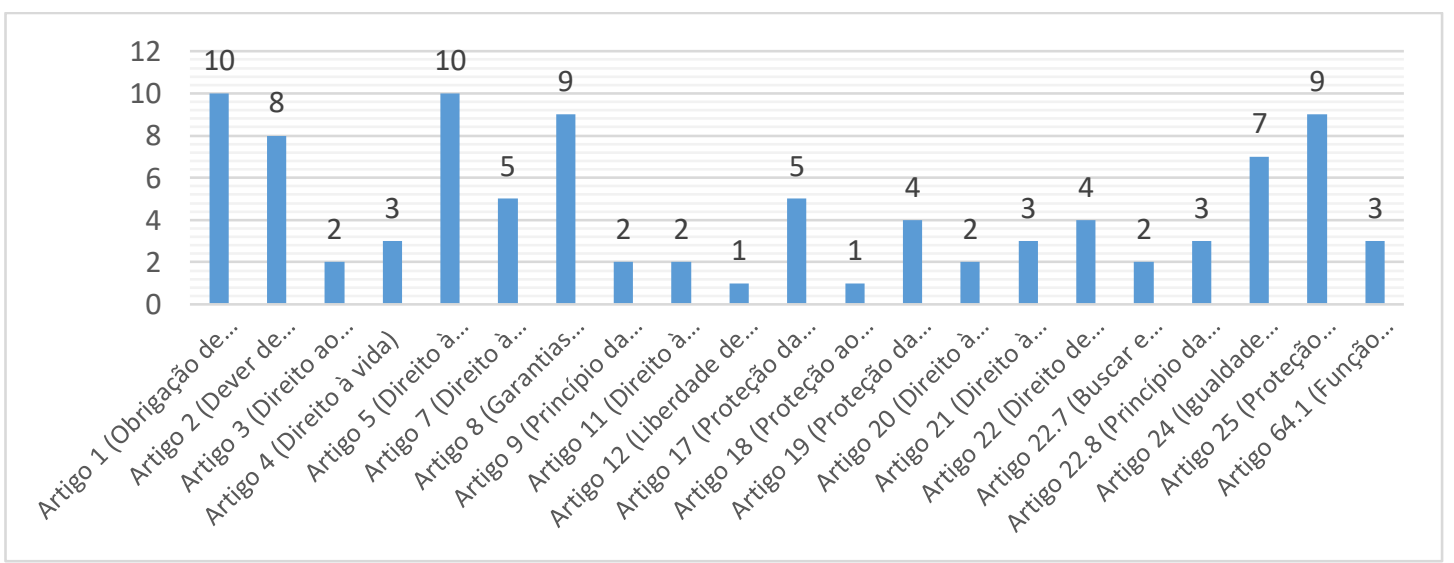

Fonte: Disponível em: <http://www.corteidh.or.cr/cf/Jurisprudencia2/index.cfm?lang=es>. Acesso em 7 de abril de 2020. 
A partir dos dados anteriormente compilados, é possível identificar determinadas categorias, por exemplo: violações que estão diretamente relacionadas à migração (art. 20 e 22, $C A D H$ ), violações atinentes às institucionalidades (art. 8 e 25, CADH), bem como aos abusos de autoridade e detenções arbitrárias (art. 5 e 7, CADH); e demais artigos que dizem respeito à proteção geral da dignidade humana.

Assim, com base nos números obtidos, foram selecionados os direitos considerados parâmetros de proteção. Conforme a sistematização esboçada na tabela 3, foram indicados dez artigos da Convenção Americana de Direitos Humanos e organizados por categorias.

Tabela 2: Sistematização dos parâmetros

\begin{tabular}{|l|l|l|}
\hline & \multicolumn{1}{|c|}{ Parâmetro Interamericano } & \multicolumn{1}{c|}{ Proteção Legal } \\
\hline 1 & Direito à igualdade e não discriminação & Art. 1.1 c/c art. 24, CADH \\
\hline 2 & Direito à liberdade e integridade pessoal & Art. 5 e 7, CADH \\
\hline 3 & Acesso à justiça, proteção e garantias judiciais & Art. 8 e 25, CADH \\
\hline 4 & $\begin{array}{l}\text { Direito à vida familiar e proteção da criança e do } \\
\text { adolescente }\end{array}$ & Art. 17 e 19, CADH \\
\hline 5 & Direito à nacionalidade & Art. 20, CADH \\
\hline 6 & Direito à circulação e residência & Art. 22, CADH \\
\hline 7 & Direito a buscar e receber asilo & Art. 22.7, CADH \\
\hline 8 & Princípio da não devolução & Art. 22.8, CADH \\
\hline
\end{tabular}

Fonte: Convenção Americana de Direitos Humanos (1969).

A sistematização obtida nesta pesquisa coincide com a compilação realizada pela Comissão Interamericana de Direitos Humanos no informe Derechos humanos de migrantes, refugiados, apátridas, víctimas de trata de personas y desplazados internos: Normas y Estándares del Sistema Interamericano de Derechos Humanos, publicado em 2015.

Deste modo, diante da aplicação dos filtros para delimitar os fundamentos que serão estudados nesta pesquisa e a obtenção dos resultados, a próxima seção será dedicada à análise dos parâmetros. 


\section{OS PARÂMETROS GERAIS DE PROTEÇÃO DOS DIREITOS HUMANOS: APLICAÇÃO EM ATENÇÃO ÀS DEMANDAS MIGRATÓRIAS}

\subsection{DIREITO À IGUALDADE E NÃO DISCRIMINAÇÃO}

O tratamento dos migrantes parte da premissa estabelecida pela Corte de que os Estados possuem faculdade para definir suas políticas migratórias, contudo, esses devem observar o princípio da igualdade perante a lei e o da não discriminação em sua aplicação, dentre outras garantias estabelecidas pela Convenção. Os princípios supracitados constituem o pilar central do Sistema Interamericano de Direitos Humanos.

Neste contexto, cumpre diferenciar o artigo 1.1 do artigo 24 da Convenção. A Corte estabelece que o primeiro possui um caráter geral, por se tratar de um dever do Estado, pois o seu conteúdo auxilia na interpretação ${ }^{2}$ de todos os demais dispositivos da Convenção. Deste modo, ao descumprir a obrigação de respeito ou de garantia de algum direito estabelecido na Convenção, o Estado viola o artigo 1.1 combinado a outro artigo específico.

Ao observar o gráfico 1 da seção 1 deste trabalho, nota-se que o artigo 1.1 da Convenção é citado em 10 dos 12 documentos analisados. A reiterada incidência refere-se ao dever do Estado de respeitar todos os direitos da Convenção.

O artigo 24, por sua vez, refere-se a uma proteção desigual da própria lei interna. Neste sentido, serão observados adiante quais critérios devem ser atendidos para que o Estado não o viole ao implementar políticas públicas, leis e práticas internas.

A relevância deste artigo da Convenção faz-se, sobretudo, em um cenário de desigualdade estrutural reiterado nos Estados do continente americano. De acordo com a Comissão Econômica para América Latina e Caribe (CEPAL, 2018),

\footnotetext{
${ }^{2}$ A estrutura da Convenção Americana de Direitos Humanos é composta pelos: 1) Deveres do Estado (Art. 1 e 2); Direitos Civis e Políticos (Art. 3 ao 25); Direitos Econômicos, Sociais e Culturais (Art. 26); [...] demais dispositivos. 
182 milhões de pessoas do continente encontravam-se em situação de pobreza. E 63 milhões estavam em condição de pobreza extrema.

O Banco Mundial revela que um a cada quatro latino-americanos identificam-se como afrodescendentes, o que totaliza 133 milhões de pessoas. Segundo o relatório "Afrodescendentes na América Latina - Rumo a um marco de inclusão", a política de branqueamento da população, que estimulava a migração europeia para a região, incentivava um viés contrário à inserção de indígenas e africanos nos informes demográficos, dificultando, portanto, a inclusão social dessa população (BANCO MUNDIAL, 2018, p. 39) ${ }^{3}$.

O princípio da igualdade e da não discriminação 4 são considerados como normas jus cogens ${ }^{5}$ e erga omnes. Essa natureza estabelece a obrigação dos Estados em respeitar e garantir o exercício dos direitos humanos, independente do status migratório da pessoa.

No Parecer Consultivo 18, de 2003, no caso Nadege Dorzema e outros vs. República Dominicana e no caso Vélez Loor vs. Panamá, a Corte foi enfática ao reconhecer o princípio da não discriminação e igual proteção perante a lei como norma jus cogens. Isto é, "o caráter de jus cogens do princípio de não discriminação implica que, por seu caráter peremptório, estas regras fundamentais devem ser observadas por todos os Estados, tenham ou não ratificado as convenções que o contêm (...)" (ColDH, 2003, p. 32).

Neste contexto, para que se obtenha a plena satisfação do direito de igualdade perante a lei e não discriminação, é necessário a observância de dois critérios. O primeiro diz respeito à proibição do tratamento arbitrário - com natureza

\footnotetext{
3 "O impacto das ideologias de branqueamento sobre a formulação de políticas públicas era claramente visível nas políticas migratórias da época, que encorajavam imigrantes europeus a se estabelecerem no continente com o intuito de progressivamente branquear a população" (BANCO MUNDIAL, 2018, p. 39).

${ }^{4}$ A discriminação encontra-se definida na Convenção Internacional sobre a Eliminação de Todas as Formas de Discriminação Racial das Nações Unidas e no Convênio 111 da Organização Internacional do Trabalho relativo à discriminação em matéria de emprego e ocupação.

${ }^{5} \mathrm{O}$ descumprimento configura grave violação de direitos humanos por serem normas peremptórias e imperativas no direito internacional, portanto, inderrogáveis pela vontade das partes. ONU. Convenção de Viena Sobre os Direitos dos Tratados, de 22 de maio de 1969. Viena, 22 mai. 1969. Art. 53.
} 
excludente, restritiva ou preferencial. E o segundo obriga a criação de condições de igualdade real frente aos grupos que tenham sido historicamente excluídos e encontram-se em maior risco de serem discriminados.

Sobre a primeira obrigação, a Corte pontuou que é permitido que o Estado faça um tratamento diferenciado entre migrantes documentados e indocumentados ou até mesmo entre nacionais e não nacionais. Contudo, distinções e discriminações são termos que não possuem o mesmo significado. As primeiras são práticas razoáveis, objetivas, proporcionais e não ofensivas aos Direitos Humanos (SANCHEZ, 2011, p. 43). Em contrapartida, o tratamento discriminatório implica em diferenças arbitrárias.

Neste mesmo contexto, a Corte proíbe práticas que sejam deliberadamente discriminatórias ou cujo impacto assim o seja. É proibido que o Estado produza situações e casos de discriminação indireta, isto é, "refletida no impacto desproporcional de normas, ações, políticas ou em outras medidas que, ainda quando sejam ou pareçam neutras em sua formulação, ou tenham um alcance geral e não diferenciado, produzam efeitos negativos para certos grupos vulneráveis" (ColDH, 2012, p. 64). Essa proibição é estendida a qualquer situação, seja jurídica ou de fato.

Quanto à segunda obrigação, que diz respeito à criação de condições de igualdade real frente aos grupos que tenham sido historicamente excluídos e encontram-se em maior risco de serem discriminados, a Corte salienta a necessidade de adotar medidas positivas para reverter ou alterar situações de caráter discriminatório existentes.

Tanto no caso Nadege Dorzema e outros quanto no caso Pessoas dominicanas e haitianas expulsas, ambos contra a República Dominicana, a Comissão Interamericana alegou a existência de um contexto de racismo, discriminação e práticas anti-haitianas em que as vítimas do caso foram submetidas a atos de violência e de marginalização por parte dos agentes estatais. Nos precedentes supracitados, a Corte determinou a existência de discriminação de fato em prejuízo das vítimas, que configurariam exemplos de discriminações estruturais (ColDH, 2012, p. 60). 
A Corte IDH já se posicionou na sua competência consultiva e contenciosa quanto à existência de vulnerabilidades atinentes aos migrantes. Miragem e Marques (2014, p. 120) definem a vulnerabilidade como "[...] uma situação permanente ou provisória, individual ou coletiva, que fragiliza, enfraquece o sujeito de direitos, desequilibrando a relação". No caso Vélez Loor vs. Panamá (CoIDH, 2010, p. 49) e na Opinião Consultiva 16 (ColDH, 1999, p. 69), o Tribunal apontou que os migrantes gozam de desigualdades reais, que obrigam os Estados a adotarem medidas de compensação.

Quando se trata das desigualdades sociais, Grusky (2001, p. 13) destaca a existência de três diferenças passíveis de gerá-las: as adscritas, as socialmente herdadas e as adquiridas. Os imigrantes sofrem com as diferenças adscritas por pertencerem a determinado grupo social e/ou vinculado ao local de nascimento.

Assim, é possível que as desigualdades sociais sejam criadas a partir de barreiras construídas para que determinados grupos sejam impedidos de usufruir certos recursos. Tais ações constituem atos de discriminação negativa ${ }^{6}$, que geram exclusão social, racismo e xenofobia.

A Corte, no caso Pessoas Dominicanas y haitianas expulsas vs. República Dominicana, destaca que no contexto da aplicação das leis migratórias, a imposição de restrições com base unicamente em suas características étnicas ou raciais, isto é, direcionadas a determinados grupos, viola o que se espera da proteção estatal dos direitos humanos. Vilela (2011, p. 90) aponta que há grupos de imigrantes que se encontram em posição privilegiada na sociedade hospedeira e outros que, ao contrário, estão em condições precárias.

Desta forma, para a efetivação dos princípios da igualdade e da não discriminação é necessário adotar medidas de natureza positiva e negativa. $O$ Estado deve comprometer-se a abster-se de realizar atos discriminatórios, assim como promover medidas de compensações - sejam judiciais ou sociais.

\begin{tabular}{l}
6 "Ser discriminado negativamente significa ser associado a um destino embasado numa \\
característica que não se escolhe, mas que os outros no-la devolvem como uma espécie de estigma. \\
A discriminação negativa é a instrumentalização da alteridade, constituída em favor da exclusão". \\
CASTEL, R. A discriminação negativa: cidadãos ou autóctones? Petrópolis: Vozes, 2008, p. 14. \\
\hline
\end{tabular} 


\subsection{DIREITO À LIBERDADE E INTEGRIDADE SOCIAL}

Os artigos 5 e 7 da Convenção dizem respeito ao direito à integridade e à liberdade pessoal. Neste estudo, optou-se pela análise conjunta desses dispositivos, tendo em vista o posicionamento da Corte Interamericana que também tem tratado ambas as matérias dessa maneira, sobretudo em casos de detenção migratória.

Este tema possui particular relevância no continente, em razão do intenso fluxo de imigrantes da América Latina e Caribe rumo aos Estados Unidos da América. Em 2019, a população latino-americana residente nos EUA representava 26,6 milhões de pessoas (OIM, 2019, p. 101).

Além disto, os Estados Unidos da América possuem o maior sistema de detenção migratória do mundo. O Estados Unidos da América operam em mais de 200 instalações de detenções migratórias. Em 2017, cerca de 300 mil imigrantes foram aprisionados no Estado7. Esses dados são ainda mais preocupantes, pois em 2015, foram detidas mais de 100 mil crianças e adolescentes.

A Corte estabelece critérios de observância no âmbito das instalações carcerárias, quando a detenção migratória for imprescindível. Essas medidas dizem respeito à atenção médica ${ }^{8}$ às pessoas privadas de liberdade, sem discriminação ${ }^{9}$; e à obrigação das detenções migratórias serem realizadas em lugares distintos das prisões penais (de pessoas condenadas ou processadas).

O artigo 7 da Convenção, por sua vez, trata do direito à liberdade pessoal. Esse dispositivo estabelece dois tipos de regulações: uma de caráter geral e demais garantias que possuem caráter específico. A violação de quaisquer um dos

\footnotetext{
7 Disponível em: < https://www.globaldetentionproject.org/countries/americas/united-states>. Acesso em 9 de abril de 2020.

${ }^{8}$ No caso Nadege Dorzema e outros vs. República Dominicana observou-se que a ausência de atenção médica, seja na forma de atendimento às vítimas feridas, omissão do diagnóstico e tratamento e descaso médico com uma das vítimas que estava grávida, acentuou a vulnerabilidade da integridade física, psíquica e moral dos envolvidos.

${ }^{9}$ No caso Vélez Loor vs. Panamá houve a privação de liberdade junto com pessoas detidas por delitos penais, superlotação penitenciária e o descaso com as situações de higiene e saúde dos encarcerados. Observa-se que o atendimento genérico, como aconteceu no caso supracitado, não é suficiente para que a obrigação seja satisfeita. A atenção específica à enfermidade também satisfaz o artigo 5 da Convenção quanto às condições de tratamento cruel, degradante e desumano.
} 
parágrafos do artigo 7 da Convenção necessariamente implica na violação do parágrafo primeiro, que trata da proteção geral (CoIDH, 2010, p. 60).

Os demais parágrafos apresentam garantias específicas como o direito de não ser privado da liberdade ilegalmente (art. 7.2), arbitrariamente (art. 7.3), a conhecer as motivações alegadas contra o detido (art. 7.4), presença do controle judicial (art. 7.5), recurso para impugnar a decisão (art. 7.6) e a proibição de detenção por dívidas (art. 7.7).

O parágrafo 2 do artigo 7 da Convenção diz respeito à proibição de privações de liberdades ilegais, tanto nos aspectos formais quanto materiais ${ }^{10}$. Ou seja, as causas e condições do encarceramento devem ter sido previamente fixadas antes do evento. A sua interpretação pode ser combinada a do parágrafo 3 do mesmo artigo, que trata do princípio da não arbitrariedade.

A Corte entendeu que o conceito de arbitrariedade contém a presença de três elementos: a incoerência, a injustiça e a imprevisibilidade (ColDH, 2012, p. 41). As privações de liberdade devem observar requisitos, tais como: finalidade legítima, idoneidade, necessidade e proporcionalidade (CoIDH, 2010, p. 53).

No caso Família Pacheco Tineo vs. Bolívia (ColDH, 2013, p. 44), a Corte determina que "a detenção de pessoas por incumprimento de leis migratórias nunca deve ser com fins punitivos". De igual modo, é necessário que os Estados disponham de medidas alternativas que possam satisfazer aos fins pretendidos, isto é, adoção de medidas menos gravosas ${ }^{11}$ sempre que possível.

É preciso esclarecer a diferenciação entre as privações de liberdade com fins migratórios e fins penais. No primeiro caso, essa medida deve ser para assegurar o comparecimento da pessoa às etapas processuais ou para aplicar uma ordem de deportação, ambas realizadas no menor prazo possível (CoIDH, 2014, p. 126). A previsão regulamenta que os Estados disponham de estabelecimentos públicos separados e destinados para esse fim, os quais não poderão ser em centro

\footnotetext{
${ }^{10}$ Como critérios formais deve-se observar a previsão em legislação doméstica, anterior a prisão. E por critérios materiais, entende-se a necessidade de estabelecer processos objetivos com causas e condições da privação de liberdade.

${ }^{11}$ A penalização da entrada irregular em um país supera os fins legítimos dos Estados em controlar as suas fronteiras e pode dar lugar a detenções desnecessárias (ColDH, 2010, p. 54).
} 
penitenciários. Neste debate, a Corte expressa particular preocupação em relação ao fenômeno da criminalização da migração ${ }^{12}$ e com a detenção de crianças e adolescentes $^{13}$. No segundo caso, há constrição do direito de ir e vir em razão da aplicação de uma pena advinda da realização de um crime, prevista no Código Penal.

Neste sentido, a fim de não violar o direito à integridade física, bem como atender aos fins legítimos, idôneos, necessários e proporcionais da privação de liberdade, a Corte estabelece que a lei deverá prever um prazo máximo, que em nenhum caso poderá ser excessivo ou indefinido. Esse parâmetro coincide com o parágrafo quarto do artigo 7 da Convenção, que prevê o dever de informar os motivos da privação de liberdade. As razões devem ser fundamentadas, individualizadas ${ }^{14}$ e periodicamente revisadas ${ }^{15}$.

O artigo 7.5 da Convenção prevê a necessidade do controle judicial da privação de liberdade, isto é, o detido deverá comparecer pessoalmente, sem demora, perante o juiz ou autoridade judicial, o qual deve ouvi-lo pessoalmente, valorar as suas explicações e decidir se procede a liberação ou mantém a privação de liberdade, conforme o caso Vélez Loor vs. Panamá, julgado pela Corte. Ressaltase, portanto, o dever de encaminhar o detido a uma audiência de custódia. Tribunal destaca que o termo colocar à disposição é satisfeito quando o indivíduo é conduzido à presença de uma autoridade, habilitada por lei a exercer as funções judiciais que tenha condições de decidir acerca da manutenção ou liberação da

\footnotetext{
12 Práticas e discursos que alimentam a percepção que os imigrantes são perigosos e que estão na origem do aumento da insegurança (ColDH, 2010, p. 55). Atribuem-se também condições de ilegalidade aos aspectos que são de natureza de irregularidades administrativas. Essa confusão terminológica converge a política criminal com a política migratória.

13 O Tribunal destacou a posição de Garante do Estado quando se tratam de crianças ou adolescentes não acompanhados ou separados de suas famílias. Neste contexto, é improcedente a privação de liberdade, tendo em vista a necessidade de proteção especial e a priorização do princípio do interesse superior da criança (ColDH, 2014, p. 58).

${ }^{14}$ A Corte (2014, p. 73) prevê também a efetividade da comunicação utilizada, isto é, a informação deve ser prestada de maneira oral ou escrita. Quanto aos encargos que lhe são atribuídos, esses precisam ser realizados de maneira escrita e em idioma adequado, que a pessoa compreenda. Se for criança, em linguagem adequada ao seu desenvolvimento e idade.

${ }^{15}$ É considerada detenção arbitrária toda e qualquer privação de liberdade fundada em argumentos como segurança e ordem pública, uma vez que a mera listagem de todas as normas aplicáveis ao caso concreto é insuficiente para avaliar a necessidade ou não da medida (CoIDH, 2010, p. 40).
} 
privação de liberdade, desde que seja dotada de imparcialidade e independência.

Assim, a exemplo do caso Vélez Loor vs. Panamá, a Corte estabeleceu que a disposição do migrante frente à presença da autoridade administrativa não é suficiente para que se satisfaça a garantia do artigo 7.5 da Convenção. O Tribunal pontuou que a autoridade anteriormente citada "[...] não possui caráter judicial nem cumpre funções judiciais" (ColDH, 2010, p. 35).

Neste sentido, a interpretação dada pela Corte aos primeiros parágrafos do artigo 7 e do artigo 5 estabelecem parâmetros de proteção à integridade física, moral e psíquica, e a liberdade pessoal no tratamento dos migrantes nas detenções migratórias. A Corte enfatiza a necessidade de distinguir a ilegalidade da irregularidade, isto é, a situação do migrante é irregular. Migrar não é um crime e não deve ser tratado como tal.

O parágrafo sexto do artigo 7 diz respeito à interposição de recursos e, por uma escolha didática, será analisado em conjunto com os artigos 8 e 25 da Convenção. A seção a seguir trata da proteção e das garantias judiciais nos processos migratórios.

\subsection{ACESSO À JUSTIÇA, PROTEÇÃO E GARANTIAS JUDICIAIS}

A migração contempla diversos cenários que podem colocar o migrante internacional diante de um processo judicial ou administrativo. Neste contexto, é possível citar desde os procedimentos migratórios ao ingressar em um Estado (trâmites relativos à regularização documental) até os processos envolvendo medidas compulsórias de saída, como a deportação e a exportação.

Nesta seção, serão analisados os artigos 8 e 25 da Convenção, que dizem respeito às proteções e garantias judiciais, isto é, o efetivo direito de acesso à justiça. Tais artigos englobam os princípios do devido processo legal, do contraditório e da ampla defesa.

No que concerne à garantia judicial, o artigo 8 da Convenção assegura que todo processo judicial ou administrativo deve resguardar as garantias mínimas processuais, como o devido processo legal e o direito de defesa. Quanto à proteção 
judicial, o artigo 25 combinado ao artigo 7.6, ambos da Convenção, garantem que toda pessoa tem o direito a um recurso simples, rápido e efetivo em face de decisão que houver violado os seus direitos. A Corte enfatiza ainda que esse recurso deve ter capacidade, de fato, de reverter a situação do indivíduo e não ser meramente ilusório.

Assim, antes mesmo de o migrante ser conduzido à presença judicial, é necessário que ele esteja devidamente assessorado para que tenha condições de produzir a sua defesa (inicial ou recursal). A assistência pode ter caráter consular, legal e/ou de interpretação/tradução (quando necessário) ${ }^{16}$.

No que concerne à assistência consular, pontua-se que essa proteção diplomática é amparada pelo artigo 36 da Convenção de Viena sobre Relações Consulares e reafirmada pela Corte na Opinião Consultiva 16 de 1999. No caso Vélez Loor vs. Panamá, a Corte (2010, p. 49) afirmou que esse direito inclui três aspectos fundamentais, quais sejam: 1) a notificação do Estado sobre a condição do indivíduo (em casos de detenção migratória), bem como do próprio indivíduo sobre o seu direito à assistência consular; 2) a viabilização de meios efetivos de comunicação entre o imigrante e o seu Estado de origem; assim como, 3) a efetiva assistência em si. O caso Tibi vs. Equador, por sua vez, destaca que o cônsul, ao ser acionado, poderá providenciar a regular inspeção das condições de prisão, tradutores e assistência legal.

Quanto à assistência jurídica, a Corte pontua que essa prestação é uma obrigação estatal, quando o migrante não tiver condições econômicas de contratar a defesa técnica. Seja através das defensorias públicas, advogados vinculados a clínicas jurídicas universitárias ou advogados privados. Os profissionais habilitados devem dispor de tempo hábil para elaborar a defesa técnica, acesso integral aos documentos do processo e fundamentação das decisões judiciais ou administrativas para a interposição de recursos. Esse direito é irrenunciável, visto que o imigrante não pode ficar à mercê do poder punitivo estatal em razão da sua condição

${ }^{16}$ Em razão da vulnerabilidade dos migrantes, o direito de acesso à justiça deve ser real e não somente formal. Para tal, exige-se a adoção de medidas de compensação (ColDH, 2003, p. 122). 
vulnerável.

Por fim, quanto às assistências estatais devidas aos imigrantes, a Corte salienta que o indivíduo deve dispor de um intérprete ou tradutor, quando necessário. De acordo com o posicionamento na Opinião Consultiva 16, essa prestação, quando solicitada, é fundamental para que o imigrante compreenda todas as orientações e etapas processuais as quais ele é submetido.

Assim, para a plena satisfação do acesso à justiça e da não violação das garantias e proteções judicias, os Estados devem comprometer-se a: prestar as informações sobre os encargos contra a pessoa e dos motivos da sua expulsão ou deportação, bem como dos seus direitos (que incluem solicitar e receber assistência consular, assessoria legal gratuita e, se for o caso, tradução ou interpretação); em caso de julgamento desfavorável, o imigrante tem o direito de interpor um recurso a fim de revisar a decisão; e ser formalmente notificado sobre a eventual decisão de expulsão e deportação, que deve estar devidamente motivada.

\subsection{DIREITO À VIDA FAMILIAR E PROTEÇÃO DA CRIANÇA E DO ADOLESCENTE}

Nos últimos anos, a migração de crianças tornou-se uma realidade global. De acordo com o relatório $A$ child is a child: Protecting children on the move from violence, abuse and exploitation, elaborado pelo Fundo das Nações Unidas para a Infância (UNICEF) e publicado em maio de 2017, cerca de 300 mil crianças desacompanhadas ou separadas dos seus familiares cruzaram as fronteiras de seus Estados de origem e foram registradas em 80 Estados entre 2015 e 2016 (UNICEF, 2017, p. 14) ${ }^{17}$.

A Corte IDH é enfática ao considerar os princípios do superior interesse da criança e da participação como norteadores em casos envolvendo crianças e

\footnotetext{
17 O número de crianças refugiadas aumentou exponencialmente em dez anos. Sendo assim, metade da população mundial de refugiados era composta por elas. De acordo com a UNICEF (2017, p. 30), os dados mundiais acerca das crianças detidas em razão da sua situação migratória, por sua vez, são imprecisos. Contudo, mais de 100 países são conhecidos por essas práticas.
} 
adolescentes. Isso implica em dispor e executar diretamente medidas de proteção a eles, que favoreçam o desenvolvimento e o fortalecimento do núcleo familiar.

A Corte expressou no Parecer Consultivo 21 (ColDH, 2014, p. 58), que "a criança tem o direito a viver com a sua família, responsável por satisfazer suas necessidades materiais, afetivas e psicológicas". Assim, as separações legais só podem ocorrer se devidamente justificadas no superior interesse da criança, de forma excepcional e, na medida do possível, temporárias.

Nos casos de crianças e adolescentes solicitantes de refúgio, é necessário que seja outorgada atenção prioritária a esses casos, tendo em vista a vulnerabilidade dos indivíduos menores de idade. Logo, as crianças devem estar assessoradas por uma representação de um membro da ACNUR (quando se tratar de solicitante de refúgio), intérprete competente, assim como representação e assessoria legal (gratuita e com capacidade especializada), realização de uma entrevista pessoal com a criança e/ou adolescente com as devidas garantias e explicações adequadas à sua faixa etária (ColDH, 2014, p. 95). Nos casos de custódia da criança quando sofrerem detenção, deportação ou expulsão dos seus parentes imigrantes e nos processos de expulsão envolvendo crianças, a Corte IDH (2014, p. 125) pontua que os Estados devem considerar as particularidades ${ }^{18}$ de cada caso.

A Corte, portanto, afirma que duas incumbências devem ser respeitadas pelo Estado quanto à vida familiar: (1) obrigação de prevenir a separação familiar e preservar a unidade familiar; e (2) a adoção de medidas positivas para garantir o exercício e usufruto dos seus direitos.

${ }^{18}$ (a) a história imigratória; (b) a consideração sobre a nacionalidade, guarda e residência dos filhos do indivíduo que se pretende deportar; (c) o alcance da ruptura familiar devido à expulsão; e (d) o alcance da perturbação na vida diária da criança. 


\section{OS PARÂMETROS ESPECÍFICOS DE PROTEÇÃO AOS DIREITOS HUMANOS DOS MIGRANTES}

O estabelecimento de critérios objetivos para a proteção dos fluxos migratórios é urgente em razão dos dados alarmantes dessa população. Os dados a seguir demonstram a relevância da temática para a região e incitam a reflexão sobre o estabelecimento de parâmetros de tratamento. Na tabela abaixo, apresentam-se dados sobre as migrações no mundo, na América Latina e nos Estados Unidos da América.

Tabela 3: Dados da migração em perspectiva comparada

\begin{tabular}{|l|l|l|l|}
\hline Números em 2019 & Mundo & $\begin{array}{l}\text { América Latina } \\
\text { e Caribe }\end{array}$ & $\begin{array}{l}\text { Estados Unidos } \\
\text { da América }\end{array}$ \\
\hline Número estimado de migrantes internacionais & 272 milhões & 11.673 .288 & 58.647 .822 \\
\hline $\begin{array}{l}\text { Proporção estimada de mulheres entre os } \\
\text { migrantes internacionais }\end{array}$ & $47,9 \%$ & 5.826 .152 & 30.359 .550 \\
\hline Número de trabalhadores migrantes & 164 milhões & 37 milhões & 4,3 milhões \\
\hline Número de refugiados & 25,9 milhões & 607.263 & 1.086 .344 \\
\hline Número de apátridas & 3,9 milhões & - & - \\
\hline
\end{tabular}

Fonte: Departamento de Asuntos Económicos y Sociales (DAES) de las Naciones Unidas < https://www.un.org/en/development/desa/population/migration/data/estimates2/estimates19.asp> Acesso em 9 de abril de 2020.

\subsection{DIREITO À NACIONALIDADE}

Os esforços para a proteção ao direito à nacionalidade partem de um compromisso universal assegurado pelo artigo 15 da Declaração Universal dos Direitos Humanos e reforçado no âmbito regional pelo artigo 20 da Convenção Americana de Direitos Humanos. As pessoas sem nacionalidade são categorizadas pelo Direito Internacional como apátridas. Assim, em consequência dessa situação, 
gozam de proteção especial por estarem mais vulneráveis a ter uma vida sem acesso aos seus direitos e marcada pela marginalização.

Um dos principais problemas para os apátridas, segundo Van Waas (2017, p. 71), é a obtenção de documentos de identificação. A autora ainda complementa que "[...] sem prova de existência, acessar serviços, envolver-se em qualquer tipo de transação e mesmo mover-se livremente pelo país pode ser impossível".

O apátrida, segundo os termos do artigo 1 do Convenção sobre o Estatuto dos Apátridas, é toda pessoa que não seja considerada por qualquer Estado, segundo a sua legislação, como seu nacional. Nesse sentido, é possível que um apátrida nunca tenha saído das fronteiras do seu Estado, assim como, em contrapartida, tenha migrado e goze do status de refugiado ou da proteção complementar.

No âmbito da Corte Interamericana, há um precedente a respeito da temática, qual seja o caso das Crianças Yean e Bosico vs. República Dominicana, uma vez que as autoridades do Registro Civil negaram a emissão de certidão de nascimento de Dylcia Yean e Violeta Bosico. Apesar de terem nascido no território dominicano e o Estado adotar o princípio ius soli na determinação da nacionalidade, as crianças permaneceram como apátridas até 25 de setembro de 2001, quando Ihes foram outorgadas as certidões.

A ausência de vínculo com algum Estado faz com que os apátridas também sejam privados do reconhecimento da sua personalidade jurídica, uma vez que a nacionalidade é considerada um pré-requisito para que um indivíduo seja declarado como tal. Neste contexto, de acordo com o entendimento da Corte (2005, p. 69), esse limbo jurídico vulnera essas pessoas, tendo em vista que lhes é negada a sua condição de sujeito de direitos.

Destaca-se que as crianças supracitadas possuíam mães de nacionalidade dominicana e pais de nacionalidade haitiana, portanto, fazem parte da população dominicana com ascendência haitiana. Assim, a Corte determina os seguintes critérios de tratamento aos filhos de pais imigrantes: o status migratório não pode ser condição para concessão de nacionalidade; o status migratório de uma pessoa não se transmite aos filhos; a condição do nascimento no território do Estado é a única a 
ser demonstrada para a aquisição da nacionalidade, no que se refere a pessoas que não teriam direito a outra nacionalidade, se não adquirem a nacionalidade do Estado onde nasceram.

A faculdade de definir os critérios de concessão de nacionalidade é reconhecida aos Estados; contudo, essa ação discricionária é limitada pelo duplo dever estatal de oferecer uma proteção sem discriminação aos indivíduos, bem como prevenir, evitar e reduzir a apatridia (ColDH, 2005, p. 60).

\subsection{DIREITO DE CIRCULAÇÃO E RESIDÊNCIA COMBINADO AO PRINCÍPIO DA NÃO DEVOLUÇÃO}

Antes mesmo de analisar o artigo 22 da Convenção, que diz respeito à circulação e residência, bem como ao princípio da não devolução, pontua-se a necessidade de diferenciar as particularidades de cada categoria de migrantes. Jubilut e Apolinário (2010, p. 279) destacam a relevância de analisar a tendência do direito internacional em criar um ramo autônomo para as migrações e, consequentemente, sujeitar todas as espécies de migrantes em uma mesma classificação genérica.

As autoras supracitadas (2010, p. 279) destacam que antes das duas guerras mundiais, a proteção das pessoas em movimento não ocupava um local de relevância nas agendas internacionais. Contudo, a Segunda Guerra Mundial gerou um enorme fluxo de pessoas deslocadas forçadamente, o que incitou a preocupação da comunidade internacional.

Diante desses desafios, surgiram as figuras dos refugiados e apátridas, isto é, pessoas em condição de hipervulnerabilidade que necessitavam de proteção especial. Deste modo, foram firmadas a Convenção de 1951 e o Protocolo de 1967 sobre os direitos dos refugiados, e as Convenções de 1954 e 1961 sobre os apátridas.

As migrações forçadas acontecem quando o elemento volitivo é inexistente ou minimizado. Neste conceito, enquadram-se os refugiados convencionais e não convencionais (deslocados por conflitos armados, desastres ambientais ou violações 
massivas de direitos humanos).

O artigo 22 da Convenção, por sua vez, trata da livre circulação e residência. Os nove parágrafos do artigo supracitado tratam de diversas garantias em relação aos deslocamentos, quais sejam: do conteúdo do primeiro parágrafo, também se depreende a proteção ao deslocado interno; do parágrafo segundo, assegura-se o direito a sair livremente de qualquer Estado, inclusive do próprio, podendo esse direito ser privado somente em virtude da lei (parágrafo 3, art. 22); o parágrafo quarto pontua que os direitos do primeiro parágrafo só podem ser restringidos mediante requisitos legais; o parágrafo quinto, por sua vez, garante a proibição de expulsão de nacionais e a privação de ingressos de nacionais dentro do seu próprio Estado (exílio forçado e proibição de reingresso).

Os parágrafos sexto, oitavo e nono do artigo 22 da Convenção tratam acerca da proteção ao imigrante internacional. Desses dispositivos depreende-se o princípio da não devolução (non-refoulement), que consagra que a pessoa não pode ser rechaçada na fronteira ou expulsa de um Estado sem uma análise adequada e individualizada do seu pedido de asilo (art. 22.8, CADC). O parágrafo sexto destaca a proibição de expulsar o imigrante que se encontre regularmente em um determinado território, salvo em cumprimento de decisão motivada por razões legais. Além disso, o parágrafo nono rechaça a expulsão coletiva de imigrantes.

O princípio da não devolução, isto é, do non refoulement é denominado como a pedra angular da proteção dos refugiados. Esse princípio possui natureza jus cogens, conforme estabelecido nos artigos 53 e 64 da Convenção de Viena sobre os Direitos do Tratados de 1969, e não pode ser derrogado pela vontade dos Estados. Assim, em virtude desse princípio de natureza imperativa, antes que o Estado proceda qualquer medida de retirada, é necessário que a pessoa tenha o seu pedido individualizado e analisado adequadamente.

A Convenção Americana dispõe a interpretação ampliada do princípio, prevendo que não somente os asilados e refugiados possuem esse direito, assim como todos que tiverem a sua integridade ou liberdade pessoal em risco, sem importar a sua condição migratória no Estado em que se encontre. Desse modo, o caso Família Pacheco Tineo vs. Bolívia destaca a necessidade de realização de 
uma entrevista pessoal, bem como avaliação prévia preliminar quando o imigrante alegar o risco à sua devolução.

Quanto à expulsão coletiva de imigrantes, destaca-se que nos casos Nadege Dorzema vs. República Dominicana e Pessoas dominicanas e haitianas expulsas vs. República Dominicana, a Corte considerou que o caráter coletivo das expulsões implica em uma decisão sumária, a qual não foram pormenorizados os critérios objetivos e as circunstâncias individuais de cada imigrante.

Destarte, a Corte estabelece as seguintes garantias mínimas que precisam ser satisfeitas, como: o imigrante deve ser informado expressamente das acusações formuladas contra ele, bem como as possibilidades jurídicas de defesa, e os seus direitos de solicitar e receber assistência consular, assessoria jurídica e, se for o caso, tradução ou intérprete; em caso de decisão desfavorável, deve the ser oportunizado à revisão perante autoridade competente; e a eventual exclusão só poderá ser realizada depois de uma decisão fundamentada conforme a lei e devidamente notificada.

\subsection{DIREITO DE BUSCAR E RECEBER ASILO}

No âmbito do Direito Internacional, é possível encontrar diversas modalidades de asilo. Na América Latina, a Corte Interamericana de Direitos Humanos destaca que existe uma "tradição latino-americana de asilo" no que concerne à concessão de asilo diplomático, asilo territorial e a não extradição por motivos políticos. A nível universal, por sua vez, encontra-se o instituto do refúgio como uma das formas de asilo.

Os doutrinadores definem que "asilo é diferente da condição de refugiado, uma vez que o primeiro constitui a instituição para a proteção, enquanto o último refere-se a uma categoria de indivíduos - entre outros - que se beneficiam dessa proteção", de acordo com o entendimento de Gil-Bazo e Nogueira (2013, p. 1).

Dentre as modalidades de asilo, o refúgio recebe proteção especial por ter um aparato próprio de funcionamento. Inicialmente, o artigo 10 da Convenção de 1951 define quem é o refugiado convencional, ou seja, é aquela pessoa que se 
encontra fora do seu Estado devido a fundado temor de perseguição por raça, religião, nacionalidade, grupo social ou opiniões políticas.

No entanto, o artigo supracitado estabelece uma limitação temporal e espacial quanto à sua utilização. Sendo que temporal aplicar-se-ia "em consequência dos acontecimentos ocorridos antes de $1^{\circ}$ de janeiro de 1951" e a limitação geográfica, pois seria utilizado, inicialmente, pelos Estados do continente europeu.

O regime jurídico internacional foi moldado em razão de um contexto maior, envolvendo as consequências das duas grandes guerras mundiais. Moraes e Ramirez (2017, p. 199) afirmam que, no intuito de prever o fenômeno do refúgio como algo passageiro, a Assembleia Geral da Organização das Nações Unidas criou o Alto Comissariado das Nações Unidas para Refugiados (ACNUR), a princípio com o mandato de três anos, para lidar com a questão dos refugiados, que vem sendo renovado até os dias atuais. No entanto, atentos ao crescimento dos deslocamentos forçados, em 1967, fora criado o Protocolo Adicional de 1967, relativo ao Estatuto dos Refugiados, que eliminou as limitações temporais e espaciais dadas ao termo refúgio convencional.

No âmbito regional, a Convenção de 1969 da Organização da Unidade Africana, dadas as necessidades locais, ampliou o termo refugiado(a), aplicando não somente aos casos definidos pela Convenção de 1951, bem como a toda pessoa que deixe o seu Estado devido a uma agressão, ocupação externa, dominação estrangeira ou a acontecimentos que perturbem gravemente a ordem pública numa parte ou na totalidade do seu Estado de origem.

Dados os fluxos transnacionais na América Latina, o termo refugiado também foi ampliado pela Declaração de Cartagena, que considerou a doutrina dos relatórios da Comissão Interamericana de Direitos Humanos. Apesar do caráter não vinculante da Declaração de Cartagena, diversos Estados incorporaram tal interpretação extensiva às suas legislações nacionais ${ }^{19}$.

\footnotetext{
${ }^{19}$ Há um crescente debate sobre a situação das pessoas deslocadas em razão dos desastres ambientais no contexto das mudanças climáticas. Esses imigrantes são conhecidos também como refugiados não convencionais, de acordo com Claro (2015, p. 219). Essa nomenclatura surgiu pois
} 
A Corte, inclusive, já expressou no Parecer Consultivo 21 de 2014 a possibilidade de concessão de proteção complementar, que é uma maneira na qual o Estado reconhece a situação, identifica o risco e tem conhecimento das suas necessidades. Ainda, segundo a ACNUR, os direitos derivados da proteção internacional deveriam basear-se nas necessidades da pessoa solicitante e não na classe de proteção internacional outorgada.

A Corte (2012, p. 54) considera que, em conformidade com os artigos 8 , 22.7, 22.8 e 25 da CADH, para que se garanta o devido processo legal nos casos de reconhecimento da condição de refúgio, é primordial: garantia das facilidades necessárias, que incluem intérprete (se preciso), representação legal, orientação adequada ao solicitante, entrevista pessoal, decisões devidamente fundamentadas, adoção do princípio da confidencialidade, prazo razoável para recorrer às decisões, bem como recurso com efeitos suspensivos.

\section{CONSIDERAÇÕES FINAIS}

Os fluxos migratórios contemporâneos são formados por diversos fatores que exigem atenção, como: a composição, a faixa etária, as motivações e os graus de vulnerabilidade. Atenta a essas condições que carecem de proteção, a Corte Interamericana, por meio de jurisprudências e pareceres consultivos, estabeleceu critérios de tratamento aos migrantes nas jurisdições dos Estados-membros.

Após o exame dos documentos do Sistema Interamericano, os resultados desta pesquisa confirmam a existência de parâmetros interamericanos de proteção dos direitos humanos dos migrantes, e indicam quais vulnerabilidades são mais resguardadas pelos precedentes continentais.

eles não são protegidos, de forma específica, por tratados internacionais ou regionais. Assim, Claro (2015, p. 164) defende a adoção de sete aspectos, considerados boas práticas, em prol da proteção dos refugiados ambientais, quais sejam: a) via da ação humanitária; b) via da proteção complementar; c) via da legislação nacional; d) via da justiça climática; e) via da responsabilidade compartilhada; f) via da judicialização do refúgio ambiental; e g) via do tratado internacional. 
Por meio dos dados estatísticos, foi possível atestar a necessidade de atenção a potenciais fenômenos que desencadeariam violações de direitos humanos, como o refúgio não convencional, a detenção migratória, a criminalização dos migrantes, os elevados índices de desigualdade social e as estruturas discriminatórias de acesso à justiça.

Os parâmetros protetivos são imperativos, pois os migrantes possuem vulnerabilidades que exigem a adoção de medidas de compensação por parte dos Estados. O princípio da igualdade e da não discriminação atesta a possibilidade de adoção de medidas diferenciais, mas sem cunho discriminatório, desde que sejam objetivas, razoáveis e necessárias.

No que tange às detenções migratórias, os parâmetros que dizem respeito à integridade e à liberdade pessoal destacam a observância da atenção médica, saúde e higiene, superlotação e distinção entre as privações de liberdade para fins punitivos e fins migratórios.

As garantias e proteções judiciais são plenamente satisfeitas quando há medidas de compensação. As assistências consulares, jurídicas e de tradutores são imprescindíveis para sanar o desequilíbrio processual. Além disso, é necessário assegurar que os recursos tenham efeito real e não meramente ilusório.

Quando se trata de crianças e adolescentes, a Corte enfatiza a importância de observar os princípios do superior interesse da criança e da proteção do núcleo familiar. Quanto ao direito à nacionalidade e de buscar e receber asilo, os Estadosmembros possuem o dever de prevenir, evitar e reduzir a apatridia e o refúgio, seja pela concessão de personalidade jurídica, proibição de expulsões coletivas e aplicação do princípio do non refoulement.

As novas manifestações de vulnerabilidades têm instigado a reexaminar a forma de tratamento dos fluxos migratórios. Pensar esses movimentos em realidades distintas exige tratos que adequem a determinados cenários, como é o caso do continente americano. Os esforços contínuos do Sistema Interamericano de Direitos Humanos em garantir e implementar direitos a esses grupos são válidos, mas revelam novos desafios à agenda regional. A contribuição dessa análise, portanto, indicou tendências da atuação da Corte e demonstrou a constante 
necessidade de criar referenciais de proteção que possam ser seguidos pelos Estados-membros.

\section{REFERÊNCIAS}

BANCO MUNDIAL. Afrodescendentes na América Latina: Rumo a um marco de inclusão. Washington: Banco Mundial, 2018.

BOBBIO, Noberto. A era dos direitos. Nova edição. Rio de Janeiro: Elsevier, 2004.

CEPAL. Panorama Social 2019. Santiago de Chile: Cepal, 2019.

CORTE INTERAMERICANA DE DIREITOS HUMANOS (CoIDH). Caso pessoas dominicanas e haitianas expulsas vs. República Dominicana. Exceções preliminares, Mérito, Reparações e Custas. Sentença de 28 de agosto de 2014. Série C. No. 282.

. Caso Familia Pacheco Tineo vs, Estado Plurinacional de Bolivia. Exceções preliminares, Mérito, Reparações e Custas. Sentença de 25 de novembro de 2013. Série C. No. 272.

Caso Nadege Dorzema e outros v. República Dominicana. Exceções Preliminares, Mérito, Reparações e Custas. Sentença de 24 de outubro de 2012. Série C. No. 251.

Caso Tibi vs. Equador. Exceções preliminares, Mérito, Reparações e Custas. Sentença de 7 de setembro de 2004. Série C. No. 114.

. Caso Vélez Loor v. Panamá. Exceções Preliminares, Mérito, Reparações e Custas. Sentença de 23 de novembro de 2010. Série C. No. 218.

Casos das crianças Yean e Bosico vs. República Dominicana. Exceções Preliminares, Mérito, Reparações e Custas. Sentença de 8 de setembro de 2005. Série C. No. 130.

. Opinião Consultiva $n^{\circ} 16$, de 1 de outubro de 1999. El derecho a la información sobre la asistencia consular en el marco de las garantías del debido proceso legal. Costa Rica, 1 outubro 1999.

Opinião Consultiva $n^{\circ} 18$, de 17 de setembro de 2003. A condição jurídica e os direitos dos migrantes indocumentados. Costa Rica, 17 setembro 2003. 
. Opinião Consultiva $n^{\circ} 21$, de 19 de agosto de 2014. Direitos e garantias de crianças no contexto da migração e/ou em necessidade de proteção internacional. Costa Rica, 19 agosto 2014.

FUNDO DAS NAÇÕES UNIDAS PARA A INFÂNCIA (UNICEF). $\boldsymbol{A}$ child is a child: Protecting children on the move from violence, abuse and exploitation. New York: UNICEF, 2017.

GIL-BAZO, Maria Teresa ; NOGUEIRA, Maria Beatriz B. El asilo en la práctica de los Estados de América Latina y África. Nuevos Temas En La Investigación Sobre Refugiados: Informe de investigación No. 249, Genebra, Jan 2013.

GRUSKY, D. The past, present, and future of social inequality. In: GRUSKY, David. (Org). Social stratification: class, race and gender in sociological perspective. Boulder: Westview, 2001.

JUBILUT, Liliana Lyra; APOLINÁRIO, Silvia Menicucci. O. S. A necessidade de proteção internacional no âmbito da migração. Revista Direito GV, São Paulo, p. 275-294, Jan/Jun 2010.

LEDESMA, Hector Faúndez. El sistema interamericano de los derechos humanos: Aspectos institucionales y procesales. Tercera edición revisada y puesta al día. San José: Instituto Interamericano de Derechos Humanos, 2004.

MARQUES, Cláudia Lima; MIRAGEM, Bruno. O novo direito privado e a proteção dos vulneráveis. 2. ed. São Paulo: Editora Revista dos Tribunais, 2014.

PALUMA, Thiago; SILVA, Bianca. G. Breve Panorama Histórico Da Política Migratória Brasileira E Análise Da Legislação Migratória De 1980 A 2017. In: PALUMA, Thiago; SQUEFF, Tatiana. (Org.). Migrações Internacionais no Século XXI: Perspectivas e Desafios. Belo Horizonte: Arraes, 2019, p. 165-188.

PALUMA, Thiago; SILVA, Bianca. G.. Os reflexos jurídicos do fluxo migratório Haitiano. In: Revista da Faculdade de Direito (Ufu), v. 47, 2019, p. 348-382.

PIOVESAN, Flávia. lus constitutionale commune latino-americano em Direitos Humanos e o Sistema Interamericano: perspectivas e desafios. Revista Direito e Práxis, v. 8, n. 2, p. 1356-1388, 2017.

SANCHEZ, Julieta Morales. Derechos de los migrantes en el Sistema Interamericano de Derechos Humanos. Ciudad del México: Comisión Nacional de Los Derechos Humanos, 2011.

SQUEFF, Tatiana de A. F. R. Cardoso; ORLANDINI, Marcia Leonora. Is there a latin american child migration law? An analysis of the 'Advisory Opinion n. 21 on the rights of child migrants? rendered by the Inter-American Court of Human Rights. In: 
Revista Videre (On Line), v. 11, p. 121-134, 2019.

VAN WAAS, Laura. Apatridia (Trad: Carolina de Abreu Batista Claro). In: CAVALCANTI, Leonardo et al. Dicionário Crítico de Migrações Internacionais. Brasília: Editora UnB, 2017.

VILELA, Elaine Meire. Desigualdade e discriminação de Imigrantes Internacionais no mercado de trabalho brasileiro. Revista de Ciências Sociais, Rio de Janeiro, v. 54, n. 1, p. 89-128, 2011. 